\title{
Quality characteristics of biscuits made from wheat and African breadfruit (Treculia africana)
}

\author{
Agu, H. O.*, Ayo, J. A., Paul, A. M. and Folorunsho, F. \\ Department of Food Science and Technology, \\ Federal Polytechnic, Bauchi, \\ P.M.B. 0231, Bauchi, Bauchi State, Nigeria. \\ *Address for correspondence E-mail:agu200lng@yahoo.com
}

\begin{abstract}
Composite biscuit was made from breadfruit/wheat flour. Dehulled breadfruit was sorted, washed, sun dried, milled and sieved to get flour. The breadfruit/wheat flour was mixed in the ratio $0: 100 \%, 10: 90 \%, 20: 80 \%, 30: 70 \%, 40: 60 \%$, 50:50\% and 60:40\% respectively and used to produce biscuits. Proximate analysis, sensory and quality evaluations were carried out on the biscuits. The proximate

from 7.18 to $8.39 \%$, protein 8.39 to $15.53 \%$, fat $9.02 \%$ to $19.78 \%$, ash 0.99 to $1.3 \%$ and carbohydrate 56.38 to $73.21 \%$. significant differences $(\mathrm{p}<0.05)$ existed in odour, taste, texture, aroma, colour and general acceptability of the biscuits. Spread ratio of the different formulations ranged from 4.54 to 6.14 while the break strength ranged from 139.0 to $299.79 \mathrm{~kg}$.
\end{abstract} composition of the biscuits ranged in values with moisture

\section{INTRODUCTION}

B iscuits may be regarded as a form of confectionery dried to a very low moisture content. According to Fayemi (1981), biscuit is defined as a small thin crisp cake made from unleavened dough. Okaka (1997) described the production of biscuits as a mixture of flour and water but may contain fat, sugar and other ingredients mixed together into dough which is rested for a period and then passed between rollers to make a sheet. Biscuits may be classified either by the degree of enrichment and processing or by the method adopted in shaping them. Based on the enrichment criterion, biscuits may be produced from hand dough, soft dough or from batters (Fayemi, 1981).

The nutritional content however varies with the type of flour used. Soft wheat flour is the suitable flour for biscuit making. This is due to its content of gliadin (a prolamin) and glutamine (glutelin) which
Keywords: Quality, wheat, African bread fruits, biscuits. under goes hydration in the presence of water, salt and sugar. This protein form a visco-elastic matrix known as gluten, being responsible for the rising nature of dough or permit substantial increase in the volume of baked product of dough and its gas retention capability (Okaka, 1997).

Nigeria being one of the tropical countries cannot grow the wheat in commercial quantity due to the country's climatic condition. Only three percent of the country's total consumption of this grain can be produced locally, therefore the industry can only survive by utilization of these availability of local grain which can either partially or completely substitute wheat in the product without adversely affecting the quality of such product (Kent, 1984).

African breadfruit shall be used as a substitute to wheat in varying ratio for biscuit baking as a local alternative flour for biscuit production. Past research 
has been carried out on biscuit production using breadfruit and some have confirmed the nutritive value of breadfruit which is high in protein (Fayemi, 1999).

African breadfruit (Treculia africana) belong to the mulberry family, Moracceae, it is of African origin and is now being grown in the most tropical and sub-tropical countries. The breadfruit seeds are found in the Eastern and Northern parts of Nigeria, that is among the Igbos, Hausas and Igalas and is a popular food in these areas. It is known as " $U k w a$ " in Igbo and "barafuta" in Hausa while among the Yorubas it is known as "Jaloke (Ife)". It can also be found in other parts of the continent (Tindall, 1983).

An African breadfruit is not a fruit as the name implies but seed in the fruit. It is seldom eaten raw, baked, boiled, roasted, fried and ground into flour and tastes like wheat bread. It is a staple food of the South Pacific. (Barrau and Massal, 1954). The aim and objectives of this study are (i) To create some sensitization and also to took into the prospect of using breadfruit (Treculia africana) as composite in the production of biscuit in the industries, (ii) to determine the acceptability of breadfruits as a substitute for biscuit based on its sensory attributes, (iii) to determine the proximate composition and quality parameters of the biscuits such as break strength and spread ratio..

\section{MATERIALS AND METHODS Source of materials}

This research was carried out at the department of Food Science and Technology, Federal Polytechnic Bauchi. The materials used such as wheat flour (Dangote), baking fat (margarine), granulated sugar, powdered milk, eggs, baking powder and salt were bought from Muda Lawal market, Bauchi while the dehulled breadfruit (Treculia africana) was bought from Jos, Plateau State. All the equipment used were from Food Science and Technology Department, Federal Polytechnic Bauchi. The chemicals were of analytical grade and purchased from Sigma ofBDH Company, UK.

\section{Production of breadfruit flour}

Dehulled breadfruit seeds were washed and sun dried in open place for 4 days to a minimum moisture content level of $12 \%$. The dried seeds were sorted, milled using a milling machine (RC 4021/Britain). The flour obtained was sieved using $0.400 \mathrm{~mm}$ sieve. The flow chart is shown in Figure 1.

\section{Production of composite biscuits}

The recipe used to produce the composite biscuit is shown in Table 1. Seven blends were obtained. The fat was creamed with sugar until fluffy, the other dry ingredients were added, then liquid ingredients. Water $(5 \mathrm{ml})$ were added to obtain the desired dough and the dough was vigorously kneaded with a dough mixer (Hobart, H600) for 30 min, (Okaka, 1997).

The dough was placed on a flat rolling table and kneaded lightly for $5 \mathrm{~min}$ as to acquire the required thickness. It was cut into round shapes using a manual biscuit cutter. The cut doughs were arranged on greased trays and baked in the oven at $200^{\circ} \mathrm{C}$ for $20 \mathrm{~min}$. The hot baked biscuits were allowed to cool for 15 min and packaged in cellop

\section{Proximate composition of biscuits}

The moisture, ash and fat contents were determined using AOAC (1984) while protein content was determined by Micro Kjeldahl method (Pearson, 1976). The carbohydrate content was by difference.

\section{Spread ratio determination}

Three rows of five well formed biscuits were made and the height measured. The biscuits were arranged horizontally edge to edge and the sum of the diameter measured with the height. The spread ratio (Gomeaz et al., 1997) was calculated as diameter/height.

\section{Break strength of biscuit}

Okaka and Isiel (1990) methods were used. Biscuit of known thickness $(0.4 \mathrm{~cm})$ was placed centrally between two parallel metal bars $(3 \mathrm{~cm}$ 
was low in carbohydrate content and according to Ihekoronye and Ngoddy (1985), wheat flour has a very high content of starch.

The mean spread ratio of the samples of composite biscuits are shown in Table 3. Wheat (100\%) sample (control) had the lowest flow/spread ratio of 4.54 compared to the other samples. Significant differences existed among the samples at $\mathrm{p}<0.05$. The low spread ratio values of the control (100\% wheat) sample showed that starch polymer molecules are highly bound with the granules and swelling is limited when heated. On cooling, the starch rapidly forms a rigid gel with capacity characteristics of large molecular aggregates (Priestley, 1979).

Substitution of wheat with other samples tend to dilute the consistency of the dough. Increased spread factor was due to the difference in particle size between the wheat flour and breadfruit flour. Wheat flour has a gelatinization temperature range of $56-62^{\circ} \mathrm{C}$, but this temperature is markedly altered and increased by physical or chemical modification which affects the strong inter-molecular bonds in the granules structure. By avoiding demodulation of the protein by chemical or heat treatment, some active amylolytic enzymes remain bound to the granule surface and their action tends to affect the viscosity and final gel strength (Priestley, 1979)

The break strength of the sample ranged from 139.88 to 299.25 as shown in Table 4. Significant differences exist on the biscuit samples $(\mathrm{p}<0.05)$. breadfruit/wheat flour (10:90\%) formulation of biscuit had a very high break strength and compared favourably with $100 \%$ wheat flour biscuit which had the highest break strength.

Significant differences $(\mathrm{p}<0.05)$ exist in odour, taste, texture, colour and general acceptability of the biscuits as shown in Table 5. Sample AXZ $(100 \%)$ wheat (control), was not significantly different from samples XAB (10:90\%), AZX (20:80\%) and ABC (60:40\%) breadfruit/wheat biscuits respectively but were significantly different from others. These three samples compared favourably with AXZ (100\%) wheat in terms of odour.

The taste of sample AXZ (100\%) wheat biscuit was not significantly different from XAB (10:90\%), $\operatorname{AZX}(20: 80 \%)$ and $A B C(60: 40 \%)$ breadfruit/wheat biscuits respectively but was significantly different from others. This equally means that the three samples compared favourably with AXZ (100\%) wheat in terms of taste. There was no significant difference in samples AXZ (0:100\%), XAB (10: $90 \%)$, AZX (20:80\%) breadfruit/wheat biscuits respectively in terms of texture but significant differences exist in other samples. This means that the two samples are as good as AXZ (100\%) wheat biscuit with respect to their texture.

The Aroma showed that AXZ (100\%) wheat biscuit was not significantly different from sample XAB (10:90\%) breadfruit/wheat biscuit but significant differences exist between the other samples. The colour of the samples showed no significant difference between AXZ (100\%) wheat biscuit and XAB (10:90\%) breadfruit/wheat biscuit but they were significantly different from the other samples. This implies that $100 \%$ wheat biscuit compared, favourably with 10:90 breadfruit/wheat biscuit in terms of colour. General acceptability showed that AXZ (100\%) wheat biscuit was not significantly different from XAB (10: $90 \%)$ breadfruit/ wheat biscuit, but was significantly different from all the other samples. Therefore, sample AXZ (100\%) wheat could be compared with sample XAB (10: $90 \%$ ) breadfruit/wheat in terms of general acceptability. Sensory evaluation of composite flour biscuits from breadfruit/wheat flour showed that substitution of the breadfruit flour to $10 \%$ level was statistically comparable to wheat flour for biscuit production.

\section{CONCLUSION}

The proximate composition showed that breadfruit has a significant nutritional influence on 
apart). Weights were added on the biscuit until the biscuit snapped. The least weight that caused the breaking of the biscuit was regarded as the break strength of biscuit.

\section{Sensory evaluation of biscuits}

The seven biscuits were subjected to sensory evaluation. Atotal of twenty untrained panelist drawn from the Federal Polytechnic, Bauchi based on their familiarity with the product were used for the evaluation. The parameters evaluated include taste, colour, flavour, aroma, texture and general acceptability. The coded samples were served in clean white plastic plates at room temperature $\left(25^{\circ} \mathrm{C}\right)$ in individual booths with adequate florescent lights. Sample presentation to the panelists was at random and one at a time. They were to eat the samples and check how much they liked or disliked each one and rate them as such. The panelists were given enough water to rinse their mouths between each sample. The nine-point Hedonic scale (Larmond, 1977) was used for the evaluation and the resulting data was analyzed using analysis of variance (ANOVA) to establish significant differences among treatment. Duncan multiple range test was used to separate means where significant differences existed (Duncan, 1955).

\section{RESULTS AND DISCUSSION}

The average protein content of the biscuits are shown in Table 2 which ranged from $8.39 \%$ for $100 \%$ wheat to $15.53 \%$. for $60 \%$ breadfruit addition. Significant differences $(\mathrm{p}<0.05)$ exist on the different biscuits. There was a general increase in the protein content with increase in the addition of breadfruit flour. According to Fayemi (1999), the percentage protein of fresh ripe breadfruit (cooked) seed is 5.25 which was far lower than the value gotten for the breadfruit and wheat flour. The variation could be as a result of difference in species (Messiaen, 1992). Due to high proportion of breadfruit in 60:40\% breadfruit/wheat sample, the biscuit had high protein content, hence the use of breadfruit to raise the protein content to more than $12 \%$ as compared with biscuits made only from wheat flour. The combination has also been found more nutritious than wheat flour alone because breadfruit flour is richer than wheat flour in lysine and other essential amino acids.

The moisture content of the breadfruit/wheat biscuits ranged from 8.39 to $7.18 \%$. Significant differences exist on the moisture content of the biscuits. There was a general decrease in the moisture content of the biscuits with increase in the addition of breadfruit. Wade and Staffor (1968), reported that the moisture content of different biscuits vary according to the type of biscuit produced, for example cream crackers has about $4.3 \%$ moisture content while digestive has about $4.5 \%$.

The fat content of the biscuits ranged from 9.02 to $19.78 \%$ with increase in breadfruit proportion. Significant differences exist on the fat content of the various biscuit. The increase in the fat content of the biscuits could be due to the application of fat during biscuit production in which 60:40\% of breadfruit/ wheat had the largest fat content and could also be due to the addition of breadfruit flour at various proportions. This is in accordance with Wade and Staffor (1968), that described digestive biscuit to have $20.5 \%$ fat content.

Ash contents of the biscuits ranged from 0.99 to $1.13 \%$. Significant differences exist on the ash contents of the biscuit. The ash content increased with increase in the breadfruit proportion. Ash is a non-organic compound containing mineral content of food and nutritionally it aids in the metabolism of other organic compounds such as fat and carbohydrate (Mcwilliam, 1978). The biscuit produced from 60:40\% breadfruit/wheat had the highest ash content. Nutritionally this means that when used as composite flour, it will improve the ash content of the product.

The carbohydrate content of the biscuits ranged from 56.38 to $73.21 \%$. According to Messiaen (1992), the higher the protein, fat, ash content, the less the carbohydrate. The specie of breadfruit used 
the biscuit most especially the protein content, which was highest in 60:40\% breadfruit/wheat flour biscuits. The quality parameters showed that $\mathrm{ABC}$ (60: 40\%) breadfruit/wheat biscuit had the highest spread ratio due to high content of breadfruit and AXZ (100\%) wheat biscuit had the highest break strength due to high gluten content in the wheat flour. It is therefore recommended that substitution of breadfruit flour at $10 \%$ level should be embarked upon by biscuit industries. This will help in conserving national foreign exchange.

\section{ACKNOWLEDGEMENT}

The authors are grateful to the Laboratory staff of Food Science and Technology Department, Federal Polytechnic, Bauchi and staff of Chemistry Laboratory, Vom Veterinary Research Institute, Jos for their technological assistance in the analysis of the samples.

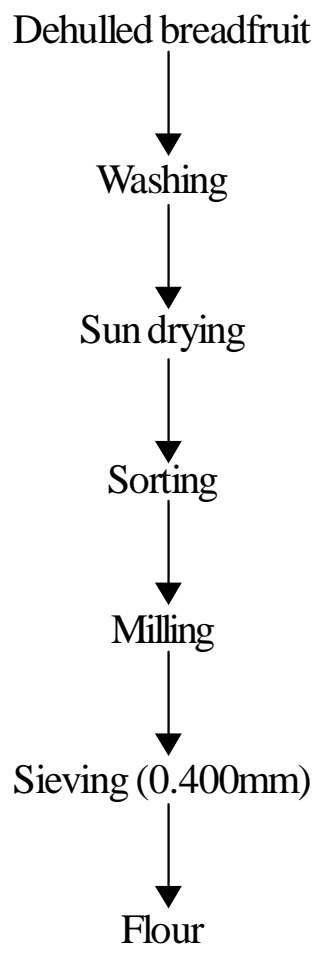

Fig. 1:Breadfruit flour production 
Quality characteristics of biscuits made from wheat and African breadfruit. Agu, et al

Table 1: Recipe for the production of composite biscuit from breadfruit and wheat flour.

\begin{tabular}{|c|c|c|c|c|c|c|c|}
\hline \multirow[t]{2}{*}{ Ingredients } & \multirow[b]{2}{*}{1} & \multicolumn{6}{|c|}{ Biscuit blends (g) } \\
\hline & & 2 & 3 & 4 & 5 & 6 & 7 \\
\hline Breadfruit flour & - & 10 & 20 & 30 & 40 & 50 & 60 \\
\hline Wheat flour & 100 & 90 & 80 & 70 & 60 & 50 & 40 \\
\hline Baking fat (margarine) & 35 & 35 & 35 & 35 & 35 & 35 & 35 \\
\hline Granulated sugar & 25 & 25 & 25 & 25 & 25 & 25 & 25 \\
\hline Baking powder & 2 & 2 & 2 & 2 & 2 & 2 & 2 \\
\hline Egg colour & 0.3 & 0.3 & 0.3 & 0.3 & 0.3 & 0.3 & 0.3 \\
\hline
\end{tabular}

Table 2: Proximate composition of biscuit (\% $)^{1,2}$

\begin{tabular}{llllll}
\hline $\begin{array}{l}\text { Breadfruit/ } \\
\text { wheat } \\
\text { flour }(\%)\end{array}$ & Protein & Fat & Moisture & Ash & Carbohydrate \\
\hline $0: 100$ & $8.39 \pm 0.67^{\mathrm{f}}$ & $9.02 \pm 0.40^{\mathrm{f}}$ & $8.39 \pm 0.67^{\mathrm{a}}$ & $0.99 \pm 0.88^{\mathrm{b}}$ & $73.21 \pm 0.25^{\mathrm{a}}$ \\
$10: 90$ & $9.70 \pm 0.23^{\mathrm{e}}$ & $11.00 \pm 0.91^{\mathrm{e}}$ & $8.13 \pm 0.90^{\mathrm{a}}$ & $1.03 \pm 0.08^{\mathrm{a}}$ & $70.14 \pm 0.89^{\mathrm{a}}$ \\
$20: 80$ & $11.00 \pm 0.80^{\mathrm{d}}$ & $12.86 \pm 0.28^{\mathrm{d}}$ & $8.00 \pm 0.24^{\mathrm{a}}$ & $1.05 \pm 0.02^{\mathrm{a}}$ & $67.09 \pm 0.65^{\mathrm{b}}$ \\
$30: 70$ & $12.13 \pm 0.22^{\mathrm{c}}$ & $14.70 \pm 0.17^{\mathrm{c}}$ & $7.96 \pm 0.40^{\mathrm{b}}$ & $1.08 \pm 0.06^{\mathrm{a}}$ & $64.13 \pm 0.42^{\mathrm{b}}$ \\
$40: 60$ & $13.20 \pm 0.11^{\mathrm{b}}$ & $16.50 \pm 0.14^{\mathrm{b}}$ & $7.61 \pm 0.90^{\mathrm{b}}$ & $1.10 \pm 0.09^{\mathrm{a}}$ & $61.59 \pm 1.02^{\mathrm{b}}$ \\
$50: 50$ & $14.92 \pm 0.31^{\mathrm{a}}$ & $18.20 \pm 0.08^{\mathrm{a}}$ & $7.32 \pm 0.06^{\mathrm{b}}$ & $1.11 \pm 0.21^{\mathrm{a}}$ & $58.45 \pm 1.66^{\mathrm{c}}$ \\
$60: 40$ & $15.53 \pm 0.21^{\mathrm{a}}$ & $19.78 \pm 0.53^{\mathrm{a}}$ & $7.18 \pm 0.54^{\mathrm{b}}$ & $1.13 \pm 0.40^{\mathrm{a}}$ & $56.38 \pm 1.47^{\mathrm{c}}$ \\
\hline
\end{tabular}

${ }^{1}$ Values are mean \pm standard deviation of duplicate determinations.

${ }^{2}$ Means with different superscript within the same column differ significantly

( $p<0.05)$ using Duncan multiple range test. 
Table 3: Spread ratio of breadfruit/wheat biscuits ${ }^{1,2}$

\begin{tabular}{lllll}
\hline $\begin{array}{l}\text { Bread fruit/ } \\
\text { wheat flour(\%) }\end{array}$ & Diameter $(\mathbf{c m})$ & Height $(\mathbf{c m})$ & Weight $(\mathbf{g})$ & Spread ratio \\
\hline $0: 100$ & $23.78 \pm 0.00$ & $5.20 \pm 2.0$ & $16.00 \pm 0.2$ & $4.57 \pm 0.90^{\mathrm{d}}$ \\
$10: 90$ & $25.25 \pm 0.50$ & $5.15 \pm 0.50$ & $16.00 \pm 0.6$ & $4.90 \pm 0.00^{\mathrm{c}}$ \\
$20: 80$ & $25.74 \pm 0.30$ & $5.20 \pm 0.5$ & $16.00 \pm 0.0$ & $4.95 \pm 0.20^{\mathrm{c}}$ \\
$30: 70$ & $25.59 \pm 1.00$ & $5.15 \pm 0.3$ & $16.40 \pm 0.5$ & $4.97 \pm 0.22^{\mathrm{c}}$ \\
$40: 60$ & $26.62 \pm 1.00$ & $5.15 \pm 0.8$ & $15.40 \pm 0.5$ & $5.17 \pm 0.22^{\mathrm{b}}$ \\
$50: 50$ & $28.98 \pm 0.00$ & $5.25 \pm 0.2$ & $15.45 \pm 0.8$ & $5.52 \pm 0.20^{\mathrm{b}}$ \\
$60: 40$ & $25.79 \pm 0.20$ & $4.20 \pm 0.2$ & $17.20 \pm 1.0$ & $6.14 \pm 0.40^{\mathrm{a}}$ \\
\hline
\end{tabular}

${ }^{l}$ Values are mean \pm standard deviation of duplicate determinations.

${ }^{2}$ Means with different superscript within the same column differ significantly $(p<0.05)$ using Duncan Multiple range test.

Table 4: Break strength of breadfruit/wheat composite biscuits ${ }^{1,2}$

\begin{tabular}{llll}
\hline Breadfruit/wheat (\%) & Maximum & Minimum & Mean \\
\hline $0: 100$ & 300 & 299.57 & $299.79 \pm 0.4^{\mathrm{a}}$ \\
$10: 90$ & 240 & 238.70 & $239.35 \pm 1.3^{\mathrm{a}}$ \\
$20: 80$ & 200 & 197.20 & $199.60 \pm 0.8^{\mathrm{b}}$ \\
$30: 70$ & 190 & 189.62 & $189.81 \pm 0.4^{\mathrm{c}}$ \\
$40: 60$ & 182 & 181.80 & $181.90 \pm 0.2^{\mathrm{c}}$ \\
$50: 50$ & 170 & 168.90 & $169.10 \pm 1.1^{\mathrm{d}}$ \\
$60: 40$ & 140 & 139.70 & $139.88 \pm 0.3^{\mathrm{e}}$ \\
\hline
\end{tabular}

${ }^{1}$ Values are mean \pm standard deviation of duplicate determinations.

${ }^{2}$ Means with different superscript within the same column differ significantly

$(p<0.05)$ using Duncan Multiple range test. 
Table 5: Sensory evaluation of breadfruit/wheat flour biscuits ${ }^{1,2}$

\begin{tabular}{llllllll}
\hline Codes & $\begin{array}{c}\text { Breadfruit/ } \\
\text { wheat }(\%)\end{array}$ & Odour & Taste & Texture & Aroma & $\begin{array}{l}\text { Colour } \\
\text { acceptability }\end{array}$ & General \\
\hline AXZ & $0: 100$ & $6.80 \pm 1.8^{\mathrm{a}}$ & $7.30 \pm 1.8^{\mathrm{a}}$ & $6.65 \pm 1.6^{\mathrm{a}}$ & $6.90 \pm 1.0^{\mathrm{a}}$ & $7.40 \pm 1.2^{\mathrm{a}}$ & $7.60 \pm 1.2^{\mathrm{a}}$ \\
$\mathrm{XAB}$ & $10: 90$ & $6.60 \pm 1.9^{\mathrm{a}}$ & $7.10 \pm 1.9^{\mathrm{a}}$ & $6.85 \pm 1.0^{\mathrm{a}}$ & $6.55 \pm 1.1^{\mathrm{a}}$ & $7.35 \pm 1.6^{\mathrm{a}}$ & $7.25 \pm 1.0^{\mathrm{a}}$ \\
$\mathrm{AZX}$ & $20: 80$ & $6.05 \pm 1.5^{\mathrm{a}}$ & $7.20 \pm 1.5^{\mathrm{a}}$ & $6.45 \pm 1.2^{\mathrm{a}}$ & $6.10 \pm 1.4^{\mathrm{b}}$ & $6.20 \pm 2.2^{\mathrm{b}}$ & $6.30 \pm 1.0^{\mathrm{b}}$ \\
$\mathrm{AFX}$ & $30: 70$ & $5.70 \pm 1.5^{\mathrm{b}}$ & $6.50 \pm 1.5^{\mathrm{b}}$ & $5.80 \pm 1.4^{\mathrm{c}}$ & $6.00 \pm 1.2^{\mathrm{b}}$ & $6.30 \pm 1.5^{\mathrm{b}}$ & $6.15 \pm 1.0^{\mathrm{b}}$ \\
$\mathrm{CAB}$ & $40: 60$ & $5.70 \pm 0.9^{\mathrm{b}}$ & $6.10 \pm 0.9^{\mathrm{b}}$ & $5.35 \pm 1.4^{\mathrm{d}}$ & $5.65 \pm 1.3^{\mathrm{c}}$ & $6.10 \pm 1.0^{\mathrm{b}}$ & $6.30 \pm 1.0^{\mathrm{b}}$ \\
$\mathrm{ABZ}$ & $50: 50$ & $5.65 \pm 1.9^{\mathrm{c}}$ & $6.05 \pm 1.9^{\mathrm{c}}$ & $6.05 \pm 1.5^{\mathrm{b}}$ & $5.55 \pm 1.8^{\mathrm{c}}$ & $5.95 \pm 1.0^{\mathrm{b}}$ & $5.90 \pm 1.2^{\mathrm{c}}$ \\
$\mathrm{ABC}$ & $60: 40$ & $6.10 \pm 1.2^{\mathrm{a}}$ & $6.85 \pm 1.2^{\mathrm{a}}$ & $6.00 \pm 1.9^{\mathrm{b}}$ & $6.10 \pm 1.4^{\mathrm{b}}$ & $6.70 \pm 1.3^{\mathrm{b}}$ & $6.65 \pm 1.3^{\mathrm{b}}$ \\
\hline
\end{tabular}

${ }^{l}$ Values are mean \pm standard deviation of 20 panelists.

${ }^{2}$ Means with different superscript within the same column differ significantly $(p<0.05)$ using Duncan multiple range test.

\section{REFERENCES}

AOAC (1984). Official method of Analysis. Association of official analytical Chemist, $13^{\text {th }}$ edition. Washington D.C., p. 278-310.

Barrau, D. and Massal, E. (1954). Pacific subsistence crops, breadfruit. South Pacific Commission Quart, Bulletin p. 105-109.

Duncan, D. B. (1955). New multiple range and multiple f test. Biometrics 11:1-11.

Fayemi, P. O. (1981). Home Economics Teacher Guide. Ibadan Macmillian Nigeria Publisher Ltd. p 201.

Fayemi, P. O. (1999). Nigerian vegetables. Heineman educational books (Nig.) Plc. p. 94-95.

Gomeaz, M. I., Obilantan, A. B., Martin, D., Madvamase, T. and Manyo, E. S. (1997). Grain quality evaluation in manual of lab procedure for quality evaluation of sorghum and pearl millet tech. manual No. 2. International crop research institute for the semi arid crops (ICRISAT). Ihekoronye, A. I. and Ngoddy, P. O. (1985).

Integrated Food Science and Technology for the Tropics. $1^{\text {st }}$ edition, Macmillian Publisher Ltd. London and Basing Stoke, p. 249-250.

Kent, N. L. (1984). Technology of Cereals. Pergamon press Ltd Headington Hill Hall, Oxford United Kingdom. p27-73.

Larmond, E. (1997). Laboratory methods for sensory evaluation of food. Publication No. 1637 Canada Department of Agriculture Ottawa.

Mcwilliam, M. (1978). Food fundamental. $3^{\text {rd }}$ edition. California State University, Los Angeles p 27-29.

Messiaen, C. M. (1992). The tropical vegetable garden. Macmillian Ltd. London and Basing Stoke p 218-247. 
Okaka, J. C. (1997). Cereals and legumes: Storage and Processing Technology. Data and microsystem publishers, Enugu, Nigeria, p 11-124.

Okaka, J. C. and Isiel, M. I. (1990). Development and quality evaluation of cowpea wheat biscuit. Nigeria Food Journal 8: 56-62

Pearson, D. (1976). The Chemical Analysis of Food. $7^{\text {th }}$ edition Churchill Livingstone Edinburgh, London and New York, p 27-72.
Priestley, J.R. (1979). Effect of Heating on Foodstuffs. National Food Research Institute Pretoria, South Africa. Applied Science Publishers Ltd., London, p 72-73, 377.

Tindall, H. D. (1983). The use of Breadfruit in Biscuit production. Paper presented at $16^{\text {th }}$ NIFST Annual Conference. Book of Abstracts p 121.

Wade and Staffor (1968). The Chemical Analysis of Foods. $7^{\text {th }}$ edition Churchill Livingstone, p205-206. 